\title{
ПОДХОДЫ К СОЗДАНИЮ ЛЕКАРСТВЕННОЙ ФОРМЫ И ОЦЕНКА МЕХАНИЗМОВ БИОЛОГИЧЕСКОГО ДЕЙСТВИЯ БИСНАФТАЗАРИНА
}

\author{
А.А.Никандрова, И.Н. Ампилогова, Ю.В. Дадали, А.Е. Смирнова, \\ В.Г. Макаров, М.Н. Макарова
}

ЗАО «Санкт-Петербургский институт фармации», 188663, Россия, Ленинградская обл., г.п. Кузьмоловский, ул. Заводская, дом 3, корп. 245.

DOI: 10.19163/MedChemRussia2021-2021-330

E-mail: nikandrova.aa@doclinika.ru

Известно, что одним из пусковых механизмов развития катаракты является истощение антиокислительного потенциала хрусталика и развитие окислительного стресса. Pезультаты исследований in vitro и in vivo, показывают, что применение антиоксиданта снижает окислительный стресс и ингибирует развитие диабетической и возрастной катаракты [1].

Strongylocentrotus droebachiensis - вид морских ежей Баренцева моря, содержащих в панцире полигидроксинафтохиноновые пигменты, обладающие выраженными антиоксидантными свойствами за счет свободных гидроксильных групп [2]. Т.к. выделенный из панцирей морских ежей пигмент биснафтазарин (рис.1) является нерастворимым в воде, то с целью создания офтальмологического средства на его основе был разработан комплекс биснафтазарина с 2-гидрокиспропил- $\beta$-циклодекстрином (БН).

В качестве модельной системы катаракты были использованы белки хрусталика глаз кролика, выделенные из гомогенатов глаз [3]. Окисление белков осуществляли путем их инкубации с 2,2'-азобис(2-амидинопропан) гидрохлоридом в течение 2 ч, что приводило к появлению фракции нерастворимых белков. При окислении белков в присутствии БН происходило ингибирование образования нерастворимых белков, схожее с действием аскорбиновой кислоты (АК): приблизительно на 40 \%. Антиоксидантная активность БН в отношении окисления белков хрусталика глаз подтверждается результатами SDS-PAGE электрофореза (рис. 2), демонстрирующими снижение образования нерастворимых белков.<smiles>CC(c1c(O)c(O)c2c(c1O)C(=O)C(O)=C(O)C2=O)c1c(O)c(O)c2c(c1O)C(O)C(O)=C(O)C2O</smiles>

Рис. 1. Структурная формула биснафтазарина (этилиден-6,6'-бис(2,3,7-тригидроксинафтазарин))

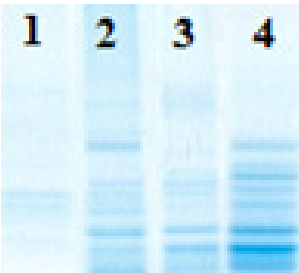

Puc. 2. Электрофореграмма белков хрусталика глаза кролика: 1-окисление без антиоксиданта, 2-в присутствии БH,

3-в присутствии АК, 4-без окисления

\section{Литература}

[1] P.F. Jacques, L.T. Chylack, S.E. Hankinson et al., Archives of Ophthalmology, 2001, 11, 1009-1019.

[2] A. Krishtopina, I. Urakova, O. Pozharitskaya et al. Pharmaceutical Chemistry Journal, 2017, 51(5), 1-4.

[3] M. Stefek, Z. Kyselova, L. Rackova, L. Krizanova, Biochim Biophys Acta, 2005, 1741(1-2), 183-90. 